\title{
Can Interfaith Research Resolve the Global Conflicts Based on Faith? ${ }^{54}$
}

\author{
Mahgoub El-Tigani Mahmoud \\ Tennessee State University
}

Doi: 10.19044/esj.2017.c1p15 URL:http://dx.doi.org/10.19044/esj.2017.c1p15

\begin{abstract}
:
Interfaith issues are quite central in the contemporary life as they had often been in ancient times. In the light of political striving, violence, and deep global concerns for the world order and peace, a great many people have been increasingly inspired to know about religions of the world, their similarities and differences, the roles they may play in conflict and conflict resolution, and the ways most desirable to get their members to know one another in justice and peace, regardless of the size of followers a religion enjoys or the tenets of faith they enjoin. Judaism, Christianity, and Islam maintain ancestral ties with a unique origin, namely the Abrahamic scriptural and spiritual heritages the Talmud, the Bible, and the Qur'an literally contained. These holy books contain a great wealth of knowledge about God and His messengers who enlightened mankind with the wisdom of religion to pursue the good life with perseverance and moral values. The discourse of interfaith ideals and practices has been in great demand globally, despite a few endeavors to enhance authentic knowledge about religion, in general, and the monotheistic religions, in particular. The need of the world is largely felt to appreciate the true meanings of religious life for individuals and social groups in order to advance the cause of peaceful co-existence between peoples of the world, especially in areas suffering deep ideological hostilities or prolonged violence through the negative influences of religious intolerance.
\end{abstract}

Keywords: Interfaith, monotheistic religions, Islam, ideological conflicts, global resolutions

\section{Introduction}

Interfaith issues have always acquired great interest from the people of faith who wanted to know possible commonalities between different systems

\footnotetext{
${ }^{54}$ This paper was prepared introductory part of a long-term research on Judaism, Christianity, and Islam interfaith knowledge to enhance the peaceful co-existence between peoples of faith in the contemporary life and global peace.
} 
of faith, besides the politicians who sought to assess the strength of religious beliefs among the public at large and the scholars who searched, in earnest, for new facts about religion as a concrete life experience. These socio-academic and professional interests in interfaith issues were quite central in the contemporary life, as they had often been in ancient times. The escalation of political striving, violence, and deep concerns for the world's healthy environment and peaceful stability inspired concerned parties in the local and global levels to acknowledge the roles religion might play in conflict and conflict resolution, and the ways most desirable to utilize scientific research to advance the cause of justice and peace, regardless of the size of followers a religion enjoyed or the tenets of faith enjoined.

We were motivated by the ongoing scholarly needs to conduct a longterm project to explore, ascertain, and publish authentic comparative works on Judaism, Christianity, and Islam to: 1) make available comprehensive comparative studies on the three religions; 2) authenticate the similarities and differences between them; and 3) provide sufficient facts about their origins, jurisprudences, and interpretations to enhance authentic knowledge about religion, in general, and these religions, in particular. The research would enhance authentic knowledge about religion, in general, and the Abrahamic religions, in particular. It would unfold in detail the meanings of life for audiences of the Abrahamic religions with a view to increase the peaceful coexistence between them and the other groups and communities of faith. It was understandable that scholarly research on the interfaith issues of the three Abrahamic religions would meet challenges of 1) the scarcity of comprehensive comparative studies in the epistemologies of these religions; 2 ) the lacking of authentic knowledge over their similarities and differences; and 3) the missing of sufficient facts on the origins, jurisprudences, and interpretations of their sources and heritages.

Emphasizing the leading role of academic research in conflict resolution, the project was proposed with due respect to the fact that the research on Judaism, Christianity and Islam would require active access to a broad corpus of knowledge in high institutes of religious education, as well as spiritual and scriptural temples. The research proposed to explore the comparative origins of the Abrahamic religions, Hebrew, Christian, and Muslim sources of which the Hebrew College, Vatican, Ethiopian and Coptic churches, and al-Azhar - among others - represented gate-keepers to collect authentic data on the religious heritages. Our proposed research would utilize complex methods of anthropological and sociological field studies, professional interviews with religious and spiritual leaderships, and archival work on the rich sources of the three religions. Assistant researchers with necessary skills on the areas of research would be assigned in the prospective 
stages of the plan. At this juncture, the paper relied heavily on Muslim accessible sources to this writer than the Jewish and Christian sources.

\section{Religion and the Abrahamic Religions}

"All religions fulfill numerous social and psychological needs...Indeed, we know of no group of people anywhere on the face of the earth who, at any time over the past 100,000 years, have been without religion... A traditional religion reinforces group norms, provides moral sanctions for individual conduct, and furnishes the substratum of common purpose and values upon which the equilibrium of the community depends." 55 Judaism, Christianity, and Islam constituted the major world religions that maintained ancestral ties with a unique origin, namely the Abrahamic scriptural and spiritual heritages the Torah, the Gospel, and the Qur'an literally contained. These holy books contained a great wealth of knowledge about God and His messengers who enlightened mankind with the wisdom of religion to spread about His Commandments for humanity to pursue the good life with perseverance and moral values.

"Torah, in Judaism, in the broadest sense the substance of divine revelation to Israel, the Jewish people: God's revealed teaching or guidance for humankind. The meaning of "Torah" is often restricted to signify the first five books of the Old Testament, also called the Law (or the Pentateuch, in Christianity). These are the books traditionally ascribed to Moses, the recipient of the original revelation from God on Mount Sinai. Jewish, Roman Catholic, Eastern Orthodox, and Protestant canons all agree on their order: Genesis, Exodus, Leviticus, Numbers, and Deuteronomy." "56 "In 1 Corinthians 15:1-8, the apostle Paul summarizes the most basic ingredients of the gospel message, namely, the death, burial, resurrection, and appearances of the resurrected Christ." "Th "The Qur'an comprehends the complete code for the Muslims to live a good, chaste, abundant and rewarding life in obedience to the commandments of Allah, in this life and to gain salvation in the next. It is the "chart of life" for every Muslim, and it is the "constitution" of the Kingdom of Heaven on Earth." 58

The subsequent sections highlighted commonalities in the moral unity of the messengers of God in Judaism, Christianity, and Islam. These sources addressed, from the most part, similar issues and offered similar solutions to the messengers of God: "15. Has the story of Moses reached thee? 16. Behold,

\footnotetext{
${ }^{55}$ Haviland, William A, 2000. Anthropology. Fort Worth: Harcourt College Publications (Ninth ed.), p.692.

56 "Torah": https://www.britannica.com/topic/Torah

57 "What is the Gospel?": Bible.org

${ }^{58}$ Ali, Anwer, "Preface to the Holy Qur'an": https://www.al-islam.org/articles/what-isthe-quran-anwer-ali
} 
thy Lord did call to him in the sacred valley of Tuwa: 17. Go thou to Pharaoh for he has indeed transgressed all bounds" (Al-Nazi'at). ${ }^{59}$ "14. O ye who believe! Be ye helpers of Allah. As said Jesus the son of Mary to the Disciples, "Who will be my helpers to (the work of) Allah." Said the disciples, "We are Allah.s helpers!" then a portion of the Children of Israel believed, and a portion disbelieved: But We gave power to those who believed, against their enemies, and they became the ones that prevailed" (Al-Saf). "2. It is He Who has sent amongst the Unlettered an apostle from among themselves, to rehearse to them His Signs, to sanctify them, and to instruct them in Scripture and Wisdom,although they had been, before, in manifest error 3. As well as (to confer all these benefits upon) others of them, who have not already joined them: And He is exalted in Might, Wise" (Al-Jum'a). "15. We have sent to you, (O men!) an apostle, to be a witness concerning you, even as We sent an apostle to Pharaoh" (Al-Muzzamil).

The Qur'an addressed the entirety of mankind in these verses as one soul: "2. Verily We created Man from a drop of mingled sperm, in order to try him: So We gave him (the gifts), of Hearing and Sight. 3. We showed him the Way: whether he be grateful or ungrateful (rests on his will)" (Al-Dahr). The Qur'an revealed clear dictates for Muslims to interact in the best manners with the People of the Book, the Christians and Jews: "125. And argue with them in ways that are best and most gracious" (Al-Nahl). It sufficed to mention the verse: "46. And dispute ye not with the People of the Book, except with means better (Than mere disputation), unless it be with those of them who inflict wrong and (injury)" (Al- 'Ankabout). "125. And argue with them in ways that are best and most gracious" (Al-Nahl).

\section{Moses, Yeshua, and Muhammad:}

Moses, Yeshua 'Īsā ibn Maryam, and Muhammad were God's messengers for missions of monotheism, humanity and mercy. The Holy Qur'an required all Muslims to believe equally in the Books and Messengers of God: "285. The Messenger believeth in what hath been revealed to him from his Lord, as do the men of faith. Each one (of them) believeth in Allah, His angels, His books, and His apostles. 'We make no distinction (they say) between one and another of His apostles.' And they say: 'We hear, and we obey: (We seek) Thy forgiveness, our Lord, and to Thee is the end of all journeys" (Al-Baqara). The Prophet of Islam said that he and Yeshua Jesus Christ "are brothers." This Hadith was rather ignored by commentators on the Judo-Christian-Muslim commonalities which were deeply rooted in the same

\footnotetext{
${ }^{59}$ See the translation of these verses and the other verses mentioned from the Qur'an in this paper in:

Ali, Abdullahi Yusuf, 1946. The Holy Qura'n Translation and Commentary, https://archive.org/details/HolyQurAnYusufAliTranslation1946Edition
} 
spiritual and ancestral sources - Abraham, the father of both Isaac and Samael of whom 'Issā and Muhammad were grand descendants, as well as a great many Prophets and messengers of God.

Muhammad's coming to the world as a Prophet of God was foretold by Jesus " 6 . And remember, Jesus, the son of Mary, said: 'O Children of Israel! I am the apostle of Allah (sent) to you, confirming the Law (which came) before me, and giving Glad Tidings of an Messenger to come after me, whose name shall be Ahmad.' But when he came to them with Clear Signs, they said, 'this is evident sorcery!"' (Al-Saf). This was earlier foretold by Moses: "10. Say: See ye? If (this teaching) be from Allah, and ye reject it, and a witness from among the Children of Israel testifies to its similarity (with earlier scripture), and has believed while ye are arrogant, (how unjust ye are!) truly, Allah guides not a people unjust" (Al-Ahqaf). ${ }^{60}$

Muhammad's first meeting with a knowledgeable monotheist occurred when his wife Khadija told him about her Christian relative, Waraqa Ibn Nufal who would ascertain to Muhammad that the meeting he had with al-Namous, Archangel Gabriel, at the Cave of Hara in Mecca occurred as well to Moses and 'Īsā. Nufal then told Muhammad he was undoubtedly the Prophet whom 'Isā predicted would be the upcoming messenger of God. ${ }^{61}$ Muhammad had been closely interacting with the Madina Jewish communities as the Hebrew jurists investigated his Prophetic mission, its signs, and authenticity. In all these sophisticated talks, it became clear to the most knowledgeable Hebrew, 'Abduhlahi ibn Salam, that Muhammad was the promised messenger of God.

What was more; the godly origins the three Prophets disseminated to their peoples carried the same commandments; as stated in the Qur'an: "44. It was We who revealed the law (to Moses): therein was guidance and light. By its standard have been judged the Jews, by the prophets who bowed (as in Islam) to Allah's will, by the rabbis and the doctors of law: for to them was entrusted the protection of Allah's book, and they were witnesses thereto: therefore fear not men, but fear me, and sell not my signs for a miserable price. If any do fail to judge by (the light of) what Allah hath revealed, they are (no better than) Unbelievers. 45. We ordained therein for them: "Life for life, eye for eye, nose or nose, ear for ear, tooth for tooth, and wounds equal for equal." But if any one remits the retaliation by way of charity, it is an act of atonement

\footnotetext{
${ }^{60}$ Yusuf Ali note 4783 read: “Among Israel there are men who understand the previous scriptures, and who find the Qur'an and its Preacher a true confirmation of the previous scriptures. They accept Islam as a fulfillment of the revelation of Moses himself! (See Deut. 18:18-19)" http://www.quran-explained.com/p/Sura-46.html

${ }^{61}$ Earlier, a Christian monk named Bahira recognized signs predicting Muhammad's Prophesy by biblical sources when he was 12 years old with Abu-Talib, his father's brother, in South Syria. See, Mohamed Nasir al-Albani, 2011: http://www.ahlalhdeeth.com/vb/showthread.php?t=236065.
} 
for himself. And if any fail to judge by (the light of) what Allah hath revealed, they are (No better than) wrong-doers."

"46. And in their footsteps We sent Jesus the son of Mary, confirming the Law that had come before him: We sent him the Gospel: therein was guidance and light, and confirmation of the Law that had come before him: a guidance and an admonition to those who fear Allah.47. Let the people of the Gospel judge by what Allah hath revealed therein. If any do fail to judge by (the light of) what Allah hath revealed, they are (no better than) those who rebel. 48. To thee We sent the Scripture in truth, confirming the scripture that came before it, and guarding it in safety: so judge between them by what Allah hath revealed, and follow not their vain desires, diverging from the Truth that hath come to thee. To each among you have we prescribed a law and an open way. If Allah had so willed, He would have made you a single people, but (His plan is) to test you in what He hath given you: so strive as in a race in all virtues. The goal of you all is to Allah. It is He that will show you the truth of the matters in which ye dispute" (Al-Maida).

\section{The Justice and Mercy of Monotheistic Religions}

"The Torah taught: "And Elokim (G-d of Justice) spoke unto Moshe saying: I am YHVH (G-d of Mercy)" (6:2). "Hear O Israel! YHVH (the G-d of Mercy), our Elokim (the G-d of Justice), G-d is One" (Devarim 6:4). ${ }^{62 ~ " A s ~}$ Moses begins his great closing addresses to the next generation, he turns to a subject that dominates the last of the Mosaic books, namely justice: "I instructed your judges at that time as follows: "Listen to your fellow men, and decide justly [tzedek] between each man and his brother or a stranger. You shall not be partial in judgment. Listen to great and small alike. Fear no one, for judgment belongs to God. Any matter that is too difficult for you, bring to me and I will hear it." Tzedek, "justice", is a key word in the book of Devarim - most famously in the verse: "Justice, justice you shall pursue, so that you may thrive and occupy the land that the Lord your God is giving you" (16: 20).

"The false contrast between Jew and Christian in The Merchant of Venice is eloquent testimony to the cruel misrepresentation of Judaism in Christian theology until recent times. Why then is justice so central to Judaism? Because it is impartial, Law as envisaged by the Torah makes no distinction between rich and poor, powerful and powerless, home born or stranger. Equality before the law is the translation into human terms of equality before God. Time and again the Torah insists that justice is not a human artefact: "Fear no one, for judgment belongs to God." Because it belongs to God, it must never be compromised - by fear, bribery, or favouritism. It is an 
inescapable duty, an inalienable right. Judaism is a religion of love: You shall love the Lord your God; you shall love your neighbour as yourself; you shall love the stranger. But it is also a religion of justice, for without justice, love corrupts (who would not bend the rules, if he could, to favour those he loves?). It is also a religion of compassion, for without compassion law itself can generate inequity. Justice plus compassion equals tzedek, the first precondition of a decent society." 63

The Gospel taught: ${ }^{64}$ "God will bring into judgment both the righteous and the wicked, for there will be a time for every activity, a time to judge every deed" (Ecclesiastes 3:17). "The Lord will judge his people" (Hebrew 10:30). "But you must return to your God: maintain love and justice, and wait for your God always" (Hosea 12:6). "He reveals the deep things of darkness and brings utter darkness into the light" (Job 12:22). "When justice is done, it brings joy to the righteous but terror to evildoers" (Proverbs 21:15). "Whoever says to the guilty, "You are innocent," will be cursed by peoples and denounced by nations. 25 But it will go with those who convict the guilty, and rich blessing will come on them" (Proverbs 24:24-25). "Evildoers do not understand what is right, but those who seek the Lord understand it fully" (Proverbs 28:5). "You have heard that it was said, 'Eye for eye, and tooth for tooth.' 39 But I tell you, do not resist an evil person. If anyone slaps you on the right cheek, turn to them the other cheek also" (Matthew 5:38-39). "24 But let justice roll on like a river, righteousness like a never-failing stream!" (Amos 5:24). "Turn from evil and do good; then you will dwell in the land forever. 28 For the Lord loves the just and will not forsake his faithful ones. Wrongdoers will be completely destroyed; the offspring of the wicked will perish. 29 The righteous will inherit the land and dwell in it forever" (Psalm 37:27-29).

"19 Do not take revenge, my dear friends, but leave room for God's wrath, for it is written: "It is mine to avenge; I will repay," says the Lord" (Romans 12:19). “. . the Lord is a God of Justice" (Isaiah 30:18-19). “... what does the Lord require of you? to act justly and to love mercy and to walk humbly with your God" (Micah 6:8). "For I, the Lord, love justice" (Isaiah 61:8-9). "And will not God bring about justice for his chosen ones, who cry out to him day and night?" (Luke 18:1-8). "Learn to do right; seek justice. Defend the oppressed. Take up the cause of the fearless; plead the case of the widow" (Isaiah 1:17). "Blessed are those who act justly, who always do what is right" (Psalm 106:3). "This what the Lord Almighty said: "Administer true justice; show mercy and compassion to one another" (Zechariah 7:9). "26

\footnotetext{
${ }^{63}$ Britain's Former Chief Rabbi, Lord Jonathan Sacks, undated. "Tzedek: Justice and Compassion."

Torah.org:https://www.ou.org/torah/parsha/rabbi-sacks-onparsha/tzedek_justice_and_compassion/

${ }^{64}$ www.biblestudytools.com/topical-verses/bible-verses-about-justice/
} 
Follow justice and justice alone, so that you may live and possess the land the Lord your God is giving you" (Deuteronomy 16:20). "7 The righteous care about justice for the poor; but the wicked have no such concern" (Proverbs 29:7)... "do not pervert justice; do not show partiality to the poor or favoritism to the great, but judge your neighbor fairly" (Leviticus 19:15). "The Lord loves righteousness and justice; the earth is full of unfailing love" (Psalm 33:5).

\section{Islam, the Last Abrahamic Religion}

The Quran taught that all Messengers of God were men upon whom God bestowed "knowledge and wisdom" to provide His missions of monotheism to humanity for justice and mercy. The apostles were refined models of leadership with perseverance to complete the missions for which they were tested by huge hardships and enormous difficulties. All apostles were believers in God and their missions as a whole: "285. The Messenger believeth in what hath been revealed to him from his Lord, as do the men of faith. Each one (of them) believeth in Allah, His angels, His books, and His apostles. 'We make no distinction (they say) between one and another of His apostles.' And they say: 'We hear, and we obey: (We seek) Thy forgiveness, our Lord, and to Thee is the end of all journeys"" (The Cow, al-Baqara). The value-orientations underlying the missions of God were strictly meant to direct humanity to the wisdom of creation: worshipping the Creator and living peacefully the good life He most graciously prescribed.

Both Muslim and non-Muslim sources revealed clear evidence on foretelling the prophet of Islam. " 6 : And remember, Jesus, the Son of Mary, said 'O Children of Israel! I am the apostle of God (sent) to you confirming the law (which came) before me, and giving Glad Tidings of an Apostle to come after me, whose name shall be Ahmad"' (Al-Saff). Yusuf Ali commented: "Ahmad", or "Muhammad", the Praised one, is almost a translation of the Greek word Periclytos. In the present Gospel of John, xiv, 16, xv, 26, and xvi, 7, the word "Comforter" in the English version is for the Greek word "Paraceitos", which means "advocate", one who called to the help of another, a kind friend", rather than "Comforter". Our doctors contend that Paraceitos is a corrupt reading for Periclytos, and that in their original saying of Jesus there was a prophecy of our holy Prophet Ahmad by name. Even if we read Paraciete, it would apply to the holy Prophet, who is "a Mercy for all creatures." 65

In the Gospel of Barnabas: "Then answered Jesus...'I therefore say unto you the messenger of God is a splendor that shall give gladness to nearly all that God hath made, for he is adorned with the spirit of understanding and of counsel, the spirit of wisdom and might, the spirit of fear and love, the spirit

${ }^{65}$ Ali. 1983. The Holy Qur'an Translation and Commentary, op. cit., p. 1540, note 5438 
of prudence and temperance; he is adorned with the spirit of charity and mercy, the spirit of justice and piety, the spirit of gentleness and patience, which he hath received from God three times more than he hath given to all his creatures. O blessed time, when he shall come to the world! Believe me that I have seen him and have done him reverence, even as every prophet hath seen him: seeing that of his spirit God giveth to them prophesy. And when I saw him my soul was filled with consolation, saying: O Mohammed, God be with thee...' And having said this, Jesus rendered his thanks to God."

"The Islam revealed to Muhammad was not different in context from the Islam of Noah, Moses, 'İsā, or the other Messengers of God. The form was different; but the context remained the same monotheism of the only God. The form of Muhammad's Islam was different for an important reason... it was a universal and eternal humane message, not limited to the Arabs, a certain tribe, people, land, environment or time; more specifically, it was a call on the human mind whenever or wherever it may be. This universality was not known in the old heavenly messages since each was addressed to a specific people in a certain time. For this, magnificent miracles were timely supportive of the messages. But when Islam came to the human rationality to take off, there was no justification for the extraordinary miracles to occur as one word "Read!" was sufficient." ${ }^{, 67}$

"The simplicity of Islam and its appeal both to reason and to the heart accounts for its tremendous appeal. With teachings about God, human responsibility and the life hereafter which are very similar to those of Judaism and Christianity, it insists on the necessity of living a pure, God-centered life following the natural dictates of a balanced mind and conscience, following the guidance transmitted through the last prophet of God, Muhammad... It honors the previous great prophets of the Bible, Noah, Abraham, Moses, David and many others, and also reiterates the belief of early Christian communities concerning the prophetic mission of Jesus, ascribing divinity to the Creator alone." $" 68$

The impact of Islam emphasis on spirituality and the good mannerism was crystal clear in Muslim societies. For example, the Sudanese African homeland, which maintained a Christian kingdom for five centuries before the advent of Islam, adopted Islam and continued to maintain "a great body of social values that help the population to live with the difficulties of life. People

\footnotetext{
${ }^{66}$ The Gospel of Barnabas, 1907. Edited and translated from the Italian MS. in the imperial library of Vienna by Lonsdale and Laura Ragg, Oxford at the Clarendon Press, p. 104 https://archive.org/stream/thegospelofbarn00unknuoft\#page/104/mode/2up/

${ }^{67}$ Bahgat, Ahmed. 1973. Anbiya Allah, Dar al-Shuruq, Cairo, $23^{\text {rd }}$ print

${ }^{68}$ Siddiqui, Elisabeth. 1998. A brief history of Islam in the United States, http:w.w.w.colostate.edu/Orgs/MSA/docs/iia.html (2/9/98)
} 
are strongly related to collective activities and the respect of the status and role of the elderly with full respect to the individual rights to act independently from the group... The prevalent values in the different parts of the country include generosity and veneration of the spiritual leaderships... The adherence of people to the codes of honor and the respect of promise are equally recognized in the everyday life." ${ }^{\prime \prime}$

Exploring the extent of achievement of these ultimate ends, the pursuit of scholars never ceased to discover new facts on religions by spiritual contemplation, or to ascertain the discourse of interfaith ideals and practices by scientific methods of research. This pursuit acquired a great attention, particularly the eminent efforts of Pope Paul and Pope Francis to strengthen sisterly relations between the Middle East interfaith groups, in addition to the promotion of religious ties with both the Azhar high institute of Muslim jurisprudence and the Hebrew spiritual leaderships including the African Hebrew Israelites. To consolidate these efforts for the stability, peace, and mutual cooperation of a region so deeply entrenched in national ideological, political and religious hostilities, scientific research would expectedly provide authentic knowledge about religion, in general, and the monotheistic beliefs, in particular.

\section{Faith and Social Change}

Despite the concreteness and authenticity of fundamental principles in the religious heritages, and a long history of civic and social intimacies, the Abrahamic interfaith relationships experienced violent political rivalries and national disputes that persisted actively in recent times with the IsraeliPalestinian warring life and the jihadist violence in Syria, Iraq, Sudan, Egypt, Myanmar, Afghanistan, Pakistan, and Nigeria to mention a few. Additionally, doctrinal disagreements continued unabated between the Sunni and the Shiite Muslims. The latter culminated, furthermore, in large-scale wars led by the Islamic State of Iraq and the Levant Syria (ISIL or ISIS) which turned to be a ruthless indiscriminate looting and killing of the Muslim and non-Muslim populations of these nations. ISIS and Al-Qaida guerilla wars in Sinai, Yemen, Libya, Nigeria, Afghanistan and Pakistan, etc., were waged against all ruling systems to impose totalitarian caliphates by force. The brutalities of this ultraviolence were tragically extended to non-Muslim societies in many parts of the world, which motivated the International Community to launch a global military effort to eradicate the al-Qaida, ISIS, and their followers. These conflicts sabotaged the right of humans to exercise freely the desirable interfaith dialogues.

${ }^{69}$ Mahmoud, Mahgoub El-Tigani. 2009. Mawsoua Sudaniya lil- 'adala al-jinaiya walijtima'iya [Sudanese Encyclopedia of Criminal and Social Justice], Cairo: Al-Fatima Press, pp. 307-8 
In Sudan, almost all of the Muslim population in Darfur was victimized by crimes against humanity for a prolonged armed conflict escalated by the ruling junta whose Omer al-Bashir presidency and his top military and political leaderships were indicted by the International Criminal Court for massive extra-judicial killings and the criminal misappropriation and destruction of the natives' property, added to rapes, tortures, and a large-scale displacement of the indigenous people to perish in the Sahara. In Iran, the Bahahi tradition, regardless of many similarities with Islam, claimed a prophetic leadership after the Prophet of Islam Muhammad who, for Muslims, was the last Prophet and Messenger of God. "The essential message of Bahá'u'lláh is that of unity. He taught that there is only one God, that there is only one human race, and that all the world's religions represent stages in the revelation of God's will and purpose for humanity. In this day, Bahá'u'lláh said, humanity has collectively come of age. As foretold in all of the world's scriptures, the time has arrived for the uniting of all peoples into a peaceful and integrated global society. 'The earth is but one country and mankind its citizens,' he wrote." 70 This faith, however, was violently outlawed in Iran, its homeland.

The political interests and the strategic military and security agenda of authoritative regimes and/or intolerant groups of faith and counter insurgents had often counteracted the spiritual goals of interfaith. Not only in the Middle East; but equally in Pakistan where "Historical Christian communities exist openly, but have to put up with stringent rules and constant monitoring, while Christian converts from Islam suffer the brunt of persecution from both radical Islamic groups and families and neighbors. Protestant Christian communities are under close scrutiny and suffer frequent attacks, especially when they are active in outreach amongst Muslims. Violent persecution is common. Christians are targets for murder, bombings, abduction of women, rape, forced marriages and eviction from home and country. Unjust and arbitrary blasphemy laws are used to punish Christians and prevent evangelism." 71

In the case of the Rohingya Muslims of Myanmar who have been consistently persecuted, murdered, and exiled forcibly in tens of thousands, Kyaw Min, Chairman of the Democracy and Human Rights Party in Burma, informed that "Burma has a Buddhist majority. Less than 9 percent of the population is Muslim but we are more than a million people." The Burmese leader then urged, "It is sad but now the U.S. is considering military and financial aid to its newest friend: Myanmar. Before that happens, Americans should demand that the Rohingya, Myanmar's most vulnerable people, receive

\footnotetext{
70 Baha'i Community of Nashville, 2017. "What is the Bahá'í Faith?" http://www.nashvillebahai.org/the-bah\%C3\%A1-i-faith/

71 Open Doors, 2017. Pakistan, https://www.opendoorsusa.org/christianpersecution/world-watch-list/pakistan/
} 
full citizenship and equal protection under the law." 72 The collaboration of democracy and human rights' political and religious entities would be an invaluable asset in all regions suffering deep ideological hostilities or prolonged violence through the negative influences of religious intolerance.

Embracing hundreds of non-monotheistic religions, a great many people shared with the Abrahamic religions the concerns for the good life of all humans and the world's justice and peace. The possibilities of closing religious and cultural gaps between these populations was never made available as it became today by the abundance of mass media and the facilities of individual and collective communications all over the world. Unfortunately, the problem rested with the unwillingness of different parties to develop in peace meaningful dialogues: "I think that we succumb to attitudes that do not permit us to dialogue: domination, not knowing how to listen, annoyance in our speech, preconceived judgments and so many others."

Apparently, the possible solutions to help resolve the IsraeliPalestinian chronic conflict, the Saudi-Yemeni Gulf-Iranian mounting crisis, the insurgency in Darfur and Sinai, the religious-based Nigerian Boko-Haram and Taliban battlefields in Afghanistan, etc., might well be advanced if a popular interfaith movement would be independently undertaken by leaderships of the Abrahamic religions and the human rights and democracy groups with equal representation of the concerned parties and logistical support from the United Nations, African Union, the Arab League, European Union, United States, and the other global entities.

\section{The Need for Mutual Respect}

The call on mutual respect by intellectual dialogue between the competing doctrines of each faith as an essential procedure to guarantee close understanding and collaboration was reluctantly met by authoritative governments and/or dogmatic institutions. In Muslim nations, for example, the dialogue between the majority billion+ Sunni groups and the 200 million Shiite adherents was unrelentingly discouraged. Back in the 1930s, a famous dialogue occurred between Imam Saleem al-Bishri, Chief of the Azhar, and the Shiite Imam 'Abd al-Hussain Sharafadeen. ${ }^{74}$ These intellectual discussions clarified much of the differences were based on jurist preferences, rather than differences in the mainstream faith; but the dialogue was not consistently pursued. Instead, political and armed confrontations evolved between Sunni governments and the Shiite in Iran, Iraq, the Gulf, and Lebanon, etc.

\footnotetext{
${ }^{72}$ Kayaw Min. 2017. "10 Things You Need to know about the persecution of Muslims in Myanmar (Burma). http://www.huffingtonpost.com/kyaw-min/myanmar-muslimsrohingya_b_4274852.html

$73 \quad$ Pope Francis Quotes.

https://www.goodreads.com/author/quotes/7034628.Pope_Francis

74 'Abd al-Hussain Sharafadeen, undated. Al-Muraga'at, Beirut: al-Wafa.
} 
The interfaith inter-and-intra doctrinal discrepancies continued for different reasons: On the top factors, we placed the struggles between conservatives and reformers within the Abrahamic groups on the issues of scriptural interpretation and indoctrination of which the women's right to enjoy eradication of all forms of discrimination increased over time. There was always a great concern to bring about consensus between the Sunni and Shiite Muslims; the Catholic and Protestant Christians; and several Jewish groups. But the interfaith activities even by continental and international organizations, including the United Nations, European Union, and the African Union, Vatican and Organization of Islamic Cooperation seemed to be negatively affected by the forces of globalization which expanded trade imbalances in the world's economy; irreconcilable military conflicts versus militant foes; urbanization hazards; and the ensuing crises of poverty, destitution, community breakdowns, morbidity, and infant mortality.

The religious relationships in between different groups of faith were often stringent, although they might share major principles of humanity and unity. The differences between the exegesis of Shari'a Madhahib or schools of Islamic law, for example, entailed a wide range of critical thinking. A great many jurists adhered to the inherited schools of Malik ibn Anas, Abu Hanifa el-Nu'man, Ahmed ibn Hanbal, and al-Shaf-'iyi who fixed the mainstream Shari'a as the Prophet explained and his companions maintained. Contemporary thinkers, nonetheless, thought creatively about new exegesis of the scripture. For example, Mahmoud Mohamed Taha taught that the Meccan verses of the Qur'an were addressed to humanity as a whole so that they were suitable in the twentieth century compared to the Medina verses of the Qur'an which, in his opinion, ceased to be applicable in modern times with respect to the status of women, the advancement to socialism, and other challenges. The unlawful trial and assassination of Taha by a dictatorial regime was a terrorizing show of religious intolerance ${ }^{75}$

Referring to Diana Eck's emphasis on pluralism as "involvement in an active engagement with one another; active attempt to arrive at an understanding; and engaging in the very differences that we have to gain, to gain a deeper sense of each other's commitments," Amir Hussain (2003) praised "the example of the religious tolerance that occurs in North America," and advised: "In order to properly do interfaith dialogue, one must have not only a deep understanding of one's own faith, but an understanding and appreciation of the faith of the dialogue partner... God speaks to us in the Qur'an about God willing our differences and our disputes. Our differences

75 Taha ideas were mainly detailed in a number of books he personally authored in Sudan, in addition to writings by critics of Shari'a Law. See for example: Abdullahi AnNa'im, 1996. Toward an Islamic Reformation: Civil Liberties, Human Rights, and International Law. Syracuse. 
(and ensuing disputes) are not to be feared, denied, or eradicated. God teaches us through our differences. It is through dialogue that we learn about ourselves, about others, and, in so doing, perhaps also about God."76

\section{The Reversed Interfaith}

The performance of peoples of faith in the Abrahamic religions passed over times of mutual respect and collaboration, as well as times of hostilities and violence over the centuries; destructive wars broke between the three groups, in addition to bilateral disputes. The holy commandments to abide by "the best ways" were not implemented for long periods of time. The local and national levels of the disputes were enlarged and deepened in the international arena by global interests of power and control, rather than beliefs and faith. Consequently, the possibilities of peaceful reconciliation between the contending groups were often diminished as the roles to be played by interfaith leaderships and loyalties retreated to occasional conferences and individual activities.

Manipulating religious banners, many faith communities and local neighborhoods fought ferocious battles under national and international banners in all continents, notwithstanding their interfaith bondages, leaving behind millions of deaths and victims of war. Amidst the withering cities and decaying ecologies, the danger of ending the whole life by nuclear weapons encompassed the planet from corner to corner. It became true that not a single spot on earth could be safe from extinction by the polluted environments and the falling ozone. The humans, for whom God enabled a glorious destiny in peaceful universality, might have well destined themselves to a final destruction. The situation posed enormous difficulties of which extremist activities evolved by the hate groups that raised the banners of religious beliefs, only to pre-empt the genuine contexts of the God-fearing humanity. There was hardly an exception in our present time, as extremist forms of intolerance infiltrated the world by one faith or another: "Islamic fundamentalism in countries such as Afghanistan, Algeria, and Iran; Jewish fundamentalism in Israel; and Hindu fundamentalism in India" or "Christian fundamentalism represented in the dramatic growth of evangelical denominations in the United States."

Pope Francis had eloquently lamented the impoverishment of world populations for the very simple fact that "Not to share one's wealth with the poor is to steal from them and to take away their livelihood."78 Little wonder,

${ }^{76}$ Ami Hussain, 2003. "Muslims, Pluralism, and Interfaith Dialogue," in Progressive Muslims on Justice, Gender, and Pluralism, edited by Safi Omid, Oxford: One World, pp. 252; 266-67.

${ }^{77}$ Haviland, William A, 2000. Anthropology, op. cit., p. 693.

78

Pope Francis

Quotes: 
all efforts to combat extremism were never effective in societies ravaged by abuses of authority and poverty; thus unescapably vulnerable to exploitation by the powerful or manipulation by the insurgent. Moreover, unavoidable conflicts erupted versus the fundamental right to privacy and the freedoms of movement and expression, in addition to the risk of conducting biased investigations by faith, ethnic origin or race. "Far-right extremists are responsible for more deaths in the United States than Islamic extremists in recent years... Obama administration's CVE - countering violence extremism - in 2011 to partner with communities to develop anti-radicalization programs... should be expanded beyond the Muslim community. A lot of the risk factors towards radicalization are common across ideological groups," Barbara Mantel (2015). ${ }^{79}$ The impact of a free, democratically-oriented public opinion in North America and Europe, however, uncovered the sources of threat and criticized the forces of hate to protect the tranquility of people. These popular efforts restricted the policy to segregate a specific faith with suspicion and harassment.

Furthermore, the tragic crimes against humanity by war toys syphoned off billions of dollars that exacerbated terminal morbidity rates and death production, instead of improving life for the billions needy and impoverished all over the world. The most costly peace making and peace keeping operations to save lives and maintain the property were operated with a blind eye to the interfaith principles of the good life. Evidently, the short-lived peace agreements between the concerned parties in the Middle-East or the other warring societies failed to meet conditionality of the powers overseeing them or to sooth the contending rivalries. This negativity never compared to the wisdom and patience of God's messengers, Moses, Yeshua, and Muhammad that guided the necessary steps to repulse the evils of competition and the lust of control. Muhammad's reconciliation with the Quraish warring group by the Hudaibiya Pact in March 627 went as far as recognizing the unbelievers' condition to obliterate from the text his name as "Messenger of God." The pact curbed violence. It magnified the wisdom of humility vis-à-vis the arrogance of power. The success of the agreement by this refined diplomacy demonstrated the need to exercise mutual respect by direct equalitarian relations to end hostilities.

\section{The Integration of Interfaith and Secular Thought}

In earlier times, the potentialities of secular thought that developed in Europe's Renaissance came about through the striving for private and public freedoms by rational thinking independently from repression of the religious

${ }^{79}$ Mantel, Barbara, 2015. "Far-Right Extremism," in: Global Issues Selections from Coresearchers. London: Sage (2017 edition), pp. 25-34. 
institution. In modern times, the outcome of the Enlightenment Era converged apparently with original dictates of religion: The International Bill of Rights, the secular movement to secure fundamental freedoms and genuine rights in the post-World War Era by the vital provisions of the Universal Declaration of Human Rights, the International Covenant on Civil and Political Rights, the International Covenant of Economic, Social and Cultural Rights, and the rest of the international legal arsenal. Amnesty International, Human Rights' Watch, and the other NGOs continued to document gross human rights violations of the international laws. But these secular safeguards were not immune from the obstacles of resolving arguments or excesses of human behavior.

Besides the brave stands of human rights and democracy activists, who embraced among their leading ranks religious thinkers and spiritual leaders throughout the world, the struggles of these activists unmasked the gross human rights' violations and abuses of authority, especially those committed by anti-democratic regimes. The collaboration of secularist and religious activists in the principled areas of justice and humanitarian support encouraged scientific research. In the multi-religious, multi-ethnic, and pluralist societies of our times, the competencies of authenticated inquiry made it possible to replace the atrocities of authoritative regimes with proper law enforcement, tolerance, and peaceful existence.

The discourse of interfaith ideals and practices via international and national organizations of faith has been in great demand globally, despite a few endeavors that enhanced relatively the authentic knowledge about religion, in general, and the monotheistic religions, in particular. The largest space possible to cross-fertilize both of the secular and religious thought might be progressively developed on the basis of scholarly dialogues on the international human rights' norms and the scriptural and spiritual sources of faith. This essential demand would be sufficiently supplied if the world's eminent leaderships of Abrahamic faith, Pope Francis and the Christian leaderships; al-Azhar's Grand Imam Ahmed al-Tayeb; the Mufti of Jerusalem; the Shiite and Sunni 'Ulama; the Copts' Pope; and the Chief Rabbinate of Israel would closely work with the Hindu and Buddhist clergy and the other leaders of faith. From all over the world, the diversity of religious beliefs would accordingly pump the venerated wisdoms unto the global soul.

To illustrate, God's revelations emphasized the eminence of intellectual thinking, contemplation, and rationality in life. The Qur'an urged the human mind to reflect, think, and work for the good life by the conscious awareness of the glorious creations of God (Al-Room; Al-Ra'ad:3,45; and AlGathiya:12-13). Ghatani (2011) noted that the Qur'anic methods to contemplate the Universe urged all humans to look into the skies and earth (Yunis:101); to see the fruition of plants (al-An'am:99); look into food 
('Abasa:24); think about the creation of man (Al-Qiyama); the raining phenomenon (Al-Nour:43); the flying birds (Al-Nour:79); benefits from cattle (Yasin: 71-73); the Kingdom of God (Al-A'raf:185); the heavens (Qaf:6); camels (Al-Ghashiya:17-20); and the mention of many names of creations: the sun, the moon, night, day, stars, man, the cow, birds, spider, bees, earthquake, thunder, and rains, etc. ${ }^{80}$

Interestingly, natural sciences were founded on the methods of systematic observation and experimentation. The possibilities of applying the discoveries of scientific research in humanities, social sciences, and natural sciences to strengthen the cross-fertilization of all different sources of knowledge were never attainable as was made available in the present times by advanced technology and the information revolution. Within this intellectual framework, which could be actively applied to overcome the mutual anti-science/antireligious bias, successful scientific interfaith dialogues might contribute largely to resolve a variety of global crises. "Of approximately 1,600 religions and denominations in the United States, about 800 were founded after $1965 \ldots$ Science, far from destroying religion... has fostered this religious boom by removing many traditional psychological props while creating, in its technological applications, a host of new problems: threat of nuclear catastrophe; health threats from pollution; unease about the consequences in biotechnology...; and fear of loss of economic security." ${ }^{\prime 1}$

The interrelationships of faith and secular thought would be useable in the search for all-encompassing solutions, rather than piecemeal approaches. Towards this far-sighted strategy, interfaith and human rights' research would have to encourage the efforts exerted by a few thinkers and professional researchers to incorporate all schools of faith in integrated perspectives to mold doctrinal differences. Because the principles of scientific research emphasized neutrality and the mutual respect for all schools and doctrines in the comparative studies of faith, the governments interested in interfaith must not exercise supervisory authority over research by planned agendas or political dictates. Scientific research on human rights and interfaith issues would have to $\boldsymbol{b e}$ fully protected from all security intrusions on the identities of researchers or the contents and findings of research, regardless of the financial support some governments or groups of faith might generously provide.

\section{Interfaith Conferences}

"The attacks of September 11, 2001 instantly heightened the American public's sensitivity toward matters of religious difference. Many Americans

\footnotetext{
${ }^{80}$ Al-Gahtani, Nora Mohamed, 2011. أساليب القرآن الكريم في دعوته الى التفكر في الآيات الكونية [The methods of Qur'anic Call to Contemplate the Universe] https://fikrislamy.wordpress.com (28 September 2011)

${ }^{81}$ Haviland, William A, 2000. Anthropology, op. cit., pp. 693-4.
} 
realized not only that non-Muslims need to learn more about Islam, but also that Muslims must better understand and articulate their own faith to themselves and others. Jane Idleman Smith examines the current American Christian-Muslim dialogue ... since 9/11 a few Muslim scholars in the West have also begun to write about these issues. Now, many Christians and Muslims are expressing their desire to move beyond theological discussion into what is often called the "dialogue of engagement" (OUP, 2007). "While many of the encounters between Islam and Christianity over the past 14 centuries have been peaceful, Americans know little about the history of religious interaction beyond the Crusades or the fear Europe felt in the face of the invasions of the Turks. (Smith's) volume is intended to educate Americans about the great diversity of Muslims in this country while illustrating how Christians and Muslims are coming together, not only to talk to each other, but to work together for the common good." 82

Many interfaith conferences played important roles in the striving of communities to live in peace. In the United States, for example, the Interfaith Conference of Metropolitan Washington's 'theological underpinnings that form the foundation of our principles and values have, at their root, our responsibility to serve humanity and these values call us into community. The truth of our common humanity is shared by all, including atheists, agnostics, and those who claim no particular religious affiliation. These values are in harmony with the best of the values undergirding the founding documents of the United States. This interfaith vision for our community is founded on the hope that leaders and citizens alike might use this fundamental truth as the basis of particular practices of citizenship and express these values legislatively across all the governmental, civic, corporate and not-for profit organizations that make up our diverse community. First and always, we are neighbors... regardless of creed, religious affiliation or non-affiliation, race, gender, gender identity, country of origin, political party affiliation, mental or physical ability, or socio-economic condition." 83

"Founded in 1970, the Interfaith Conference of Greater Milwaukee is a non-profit organization through which the regional leaders and adherents of 17 member denominations and faiths dialogue to build relationships conduct educational programs to foster public understanding and tolerance, and work together on social-justice issues to improve the quality of life for everyone. Several non-member faiths also participate in the planning and running of many of our events and activities. The Conference's underlying emphasis is

\footnotetext{
${ }^{82}$ Smith, Jane Idleman. 2007. Muslims, Christians, and the challenge of interfaith dialogue, New York: OUP.

$83 \mathrm{http} / / /$ ifcmw.org/wp-content/uploads/2017/01/Faith-Leaders-Vision-Statement1.30.17.pdf
} 
"to uphold the dignity of every person and the solidarity of the human community." 84

The 12th Doha Interfaith Dialogue Conference (2016) under the theme "Spiritual and Intellectual Safety in the Light of Religious Doctrines," discussed the issue of religion as a humanitarian unity for spiritual and intellectual security of human societies: ${ }^{85}$ "At present, the conference is designed to promote understanding, respect and cooperation among women of all faiths and to facilitate opportunities for dialogue. The ultimate goal is to involve all faith groups in the crafting of the annual conference. The program allows women of faith to examine the ways that different religious affiliations shape a person's view of the world and opinions on contemporary issues." 86 This international forum persuaded jurists and many spokespersons for the institutes of learning to participate. But the Doha Interfaith Conference was perfectly silent vis-à-vis the Darfuri participants who spoke out for the adoption of workable resolutions to the global crisis of Darfur, which the International Criminal Court pursued legally versus Omer al-Bashir and his military and political accomplices for the sake of justice and the human rights of millions victimized by the jihadist regime in Sudan.

\section{Conclusion}

Interfaith issues received central attention in modern life, as they had in ancient times. The diversity of faith in North America, as well as other continents, exhibited increased believers of Islam, Buddhism, and Hinduism side-by-side with the dominant Christian groups. The need of the world was largely felt to appreciate the true meanings of religious life for individuals and social groups in order to advance the cause of peaceful co-existence between peoples of the world, especially in areas suffering deep ideological hostilities or the prolonged violence of religious intolerance. A great many people were inspired to know about religions of the world and the ways most desirable to get their members to know one another in justice and peace, regardless of the size of followers a religion enjoyed or the tenets of faith enjoined. To fulfill this global need, scientific research should be fully supported to help resolve the global conflicts of faith in the first place.

Our paper argued that the interfaith ideological and organizational entities would probably ensure successful results were the interfaith dialogue actively operated via a popular movement by non-governmental intellectuals assisted by professional scientific researchers. Hansen (2015) concluded in his research on the established society and religion discourse influencing interfaith dialogue on the Christian-Muslim relations in Egypt: "the two major discourses found to have impact on the dialogue were national unity and

\footnotetext{
${ }^{84} \mathrm{http}$ ///interfaithconference.org/cms-view-page.php?page=mission-statement

${ }^{85} \mathrm{http} / / / q a t a r c o n f e r e n c e s . o r g /$ interfaith2016/

${ }^{86} \mathrm{http} / / / \mathrm{www}$. womeninterfaithstl.org/
} 
monopoly of religious faith." This dialogue, however, was "preventing many of the interviewees from realizing or admitting the obvious discrimination and violent incidents between Muslims and Christians." The implication was clear: monopolizing and manipulating religious faith, the authority intrusions that emphasized national unity affected negatively the popular nature of the dialogue.

Quite evidenced in the national level, it was equally clear in the global dialogues that the imposition of political agenda and military strategies above the interfaith concerns for the momentous needs of human rights and fundamental freedoms would inevitably damage the dialogue. Yes, interfaith research could possibly help to resolve the global conflicts based on faith. Whenever academic research would be provided with the necessary requirements of scientific research and conscientious approval by the contending parties, it would help to accomplish peace and justice to the peoples victimized by wars, social ills, and the power jealousies and monopolies. By firm reduction of the massive budgets allocated for the global production of destruction by the huge trade of armament to the detriment of world peace and human progression, there would be a real opportunity to move on with intellectual and spiritual life for the betterment of humanity.

\section{References:}

1. Ali, Abdullahi Yusuf, 1946. The Holy Qura'n Translation and Commentary, https://archive.org/details/HolyQurAnYusufAliTranslation1946Editio n

2. Bahgat, Ahmed. 1973. Anbiya Allah, Dar al-Shuruq, Cairo, $23^{\text {rd }}$ print

3. Britain's Former Chief Rabbi, Lord Jonathan Sacks, undated. "Tzedek: Justice and Compassion."

4. Hansen, Henrik, 2015. Christian-Muslim Relations in Egypt: Politics, Society and Interfaith Encounters. London: L.B. Tauris.

5. Haviland, William A, 2000. Anthropology. Fort Worth: Harcourt College Publishers. (Ninth edition).

6. Hussain, Amir, 2003. "Muslims, Pluralism, and Interfaith Dialogue," in Progressive Muslims on Justice, Gender, and Pluralism, edited by Safi Omid, Oxford: One World,

7. Lonsdale and Laura Ragg, 1907. The Gospel of Barnabas. Edited and translated from the Italian MS. in the imperial library of Vienna. Oxford at the Clarendon Press, https://archive.org/stream/thegospelofbarn00unknuoft\#page/104/mod e/2up/ 
8. Mahmoud, Mahgoub El-Tigani. 2009. Mawsoua Sudaniya lil- 'adala al-jinaiya wal-ijtima'iya [Sudanese Encyclopedia of Criminal and Social Justice], Cairo: Al-Fatima Press.

9. Mantel, Barbara, 2015. "Far-Right Extremism," in: Global Issues Selections from Co-researchers. London: Sage (2017 edition).

10. Omid, Safi (ed.), 2003. The Progressive Muslim on justice, gender, and pluralism. Oxford: One World Publications.

11. Open Doors, 2017. Pakistan, https://www.opendoorsusa.org/christianpersecution/world-watch-list/pakistan/

12. Siddiqui, Elisabeth. 1998. A brief history of Islam in the United States, http:w.w.w.colostate.edu/Orgs/MSA/docs/iia.html (2/9/98)

13. Sharafadeen, 'Abd al-Hussain. Undated. Al-Muraga'at, Beirut: alWafa.

14. Smith, Jane Idleman. 2007. Muslims, Christians, and the challenge of interfaith dialogue, New York: OUP.

15. Torah.org:https://www.ou.org/torah/parsha/rabbi-sacks-onparsha/tzedek_justice_and_compassion/ 